\title{
Acute infection after retinal detachment
} surgery

\author{
R. A. HitGhings, I. S. LEVY, AND A. H. GHIGNELL \\ From Moorfields Eye Hospital, City Road, and St. Thomas' Hospital, London
}

Infection of silastic sponge implants after retinal detachment surgery continues to present a problem (Lincoff, Nadel and O'Connor, I970; Russo and Ruiz, I97 ; Flindall, Norton, Curtin and Gass, I97I ; Ruben and Fitzgerald, I972). The widespread adoption of cryotherapy has changed the character of this infection from an acute syndrome with scleral abscess formation and intraocular signs, to that of an extraocular granuloma of later onset with minimal intraocular signs (Lincoff and others, 1970). Our experience has been somewhat different, and in this paper we report a series of Io postoperative infections occurring within 2 weeks of surgery, seven of which showed marked signs of intraocular inflammation.

\section{Materials and methods}

$4^{16}$ cases of retinal detachment, treated at Moorfields Eye Hospital, City Road, and at St. Thomas' Hospital over a 2-year period, were studied. All had silastic implants buckled over full-thickness sclera with cryotherapy and in some cases drainage of subretinal fluid (SRF). All had preoperative cultures and antibiotic drops before and after surgery, and the operative area was irrigated with antibiotic solution before wound closure. Routine systemic and subconjunctival antibiotics and steroids were not used.

\section{Results and clinical features}

Ten patients $(2 \cdot 4$ per cent.) presented with a postoperative infection within the first 2 weeks of surgery (Table); a silastic sponge had been used in each. One had had surgery 2 years before and this had been complicated by infection, but there was no evidence of preoperative infection on this second occasion.

There was a characteristic mode of presentation: pain in the immediate postoperative period was much greater than that normally expected after retinal detachment surgery. In three cases the pain was dramatically relieved after a spontaneous discharge with the formation of a sinus. There was marked chemosis with upper and lower lid oedema in all cases, while five developed some proptosis with reduced eye movements. All developed a mucopurulent discharge.

In the three cases in which SRF was not drained, there was no evidence of intraocular inflammation. In contrast, in the seven cases in which subretinal fluid was drained signs of intraocular inflammation were observed. This was seen as a vitreous haze, initially localized to the site of the implant, but later becoming generalized, together with a flare and cells in 
Table Clinical particulars of ten cases

\begin{tabular}{|c|c|c|c|c|c|c|c|}
\hline Case no. & $\begin{array}{l}\text { Preoperative } \\
\text { culture }\end{array}$ & $\begin{array}{l}S R F \\
\text { drained }\end{array}$ & $\begin{array}{l}\text { Onset of } \\
\text { symptoms } \\
\text { (pain) } \\
\text { (day) }\end{array}$ & $\begin{array}{l}\text { Onset of } \\
\text { vitreous } \\
\text { haze (day) }\end{array}$ & $\begin{array}{l}\text { Onset of } \\
\text { mucopurulent } \\
\text { discharge (day) }\end{array}$ & $\begin{array}{l}\text { Removal of } \\
\text { plomb } \\
(\text { day })\end{array}$ & $\begin{array}{l}\text { Postoperative } \\
\text { culture }\end{array}$ \\
\hline I & Sterile & Yes & 4 & 6 & 4 & 28 & Staph. aureus \\
\hline 2 & Staph. aureus & Yes & 3 & 3 & 3 & 8 & Staph. aureus \\
\hline 3 & Staph. aureus & Yes & 2 & I0 & 2 & 13 & Sterile \\
\hline 4 & Staph. albus & Yes & I & 2 & 2 & 35 & Staph. aureus \\
\hline 5 & Sterile & Yes & 5 & 7 & 9 & I 4 & Sterile \\
\hline 6 & Sterile & Yes & 3 & 7 & 3 & I9 & Staph. aureus \\
\hline 7 & Sterile & Yes & I & I & 2 & 12 & Staph. aureus \\
\hline 8 & Sterile & No & 2 & None & 10 & $5^{6}$ & Sterile \\
\hline 9 & Sterile & No & 2 & None & 24 & 24 & Sterile \\
\hline 10 & Staph. albus & No & 2 & None & 5 & 28 & Staph. albus \\
\hline
\end{tabular}

the anterior chamber. The retina flattened in five of these seven cases without further surgery but in the other two cases it remained detached, and the inflammatory process, resulting in vitreous fibrosis, was a contributory factor to failure.

Although local and systemic antibiotic therapy partially relieved the symptoms and signs, resolution did not occur until the implant was removed. After removal, resolution was rapid and complete.

The preoperative cultures grew Staphylococcus aureus in two cases and Staphylococcus albus in two. Postoperative cultures grew Staphylococcus aureus in four cases and Staphylococcus albus in a further two cases. In three cases all cultures were sterile.

\section{Discussion}

The source of infection in detachment surgery is bacterial contamination from the conjunctiva, lid margins, and surrounding skin (Lincoff and others, 1970). In our series the organisms grown from the routine preoperative conjunctival 'swab' bore little relation to those cultured from the infected sponges. Such preoperative cultures would thus seem to be a poor guide to the nature of any subsequent postoperative infection.

Acute postoperative bacterial infection has to be distinguished from other causes of intraocular inflammation after detachment surgery, particularly anterior segment ischaemia and uveitis after excessive cryotherapy.

Anterior segment ischaemia may follow both encircling (Knox, 197I) and local (Easty and Chignell, 1973) indentation procedures. There is usually a latent period of 2 to 3 days before the signs of diffuse epithelial oedema of the cornea, an exudative uveitis, and iris stromal oedema, become apparent (Crock, 1967 ). The major point of differentiation between ischaemia and infection is the absence of a mucopurulent discharge in the former. Iris fluorescein angiography is a useful diagnostic aid in cases of anterior segment ischaemia (Easty and Chignell, 1973).

A reaction to excessive cryotherapy (Chignell, Revie and Clemett, 1971) does not usually present until the fifth day; there is pain with vitreous haze and an anterior uveitis, but no mucopurulent discharge. Systemic steroids produce a rapid resolution of the signs and symptoms. 
A considerable difference in intraocular involvement between those eyes in which SRF was drained and those in which it was not suggests that the sclerotomy produced at drainage allows the intraocular spread of inflammation, while an intact sclera seems to act as an efficient barrier. Thus, the non-drainage procedure advocated by Custodis (1953), Lincoff, Baras, and Maclean (1965), and Scott (1970), by maintaining the integrity of the scleral envelope, protects the eye against the intraocular spread of early postoperative infection.

\section{Summary}

In ten ( $2 \cdot 4$ per cent.) of $4^{1} 6$ surgical procedures for retinal detachment an early acute postoperative infection of the silastic sponge implant developed, with a characteristic mode of presentation. In all cases the implant was eventually removed. Of the seven that had drainage of subretinal fluid all developed intraocular inflammation. The role of the intact sclera in preventing the spread of intraocular inflammation is emphasized.

We should like to thank Mr. L. G. Fison and Mr. J. Winstanley for permission to study their cases, and Miss Lorna Martin for secretarial assistance. This work was in part supported by the Clothworkers' Company.

\section{References}

Chignell, A. H., ReVie, I. H. s., and Clemett, R. S. (1972) Trans. ophthal. Soc. U.K., 91, 635 GROGK, G. (1967) Ibid., 87, 513

Custodis, E. (1953) Ber. dtsch. ophthal. Ges., 58, 102

EASTY, D. L., and GHignell, A. H. (1973) Brit. J. Ophthal., 57, i 8

Flindall, R. J., NORTON, E. W. D., GURTIN, v. T., and GAss, J. D. M. (I97I) Amer. 7. Ophthal., 71, 835

KNOX, D. L. (I97I) Trans. ophthal. Soc. U.K., 9I, 2 I 3

Lincoff, h. A., Baras, I., and malean, J. M. (I965) Arch. Ophthal. (Chicago), 73, i6o

- NADEL, A., and o'CONNOR, P. (I970) Ibid., 84, 42 I

RUBIN, M. L., and FITZGERALD, C. R. (I972) Karger, Basel (in press)

Russo, c. E., and RuIz, R. s. (I97 I) Arch. Ophthal. (Chicago), 85, 647

scotт, J. D. (1970) Trans. ophthal. Soc. U.K., 90, 57 